\title{
FEATURE The carbon sequestration potential of terrestrial ecosystems
}

Rattan Lal, Pete Smith, Hermann F. Jungkunst, William J. Mitsch, Johannes Lehmann, P.K. Ramachandran Nair, Alex B. McBratney, João Carlos de Moraes Sá, Julia Schneider, Yuri L. Zinn, Alba L.A. Skorupa, Hai-Lin Zhang, Budiman Minasny, Cherukumalli Srinivasrao, and Nijavalli H. Ravindranath

$\mathrm{T}$ errestrial ecosystems, comprising vegetation and soil in uplands and wetlands, significantly impact the global carbon (C) cycle and, under natural conditions, are a sink of atmospheric carbon dioxide $\left(\mathrm{CO}_{2}\right)$ and methane $\left(\mathrm{CH}_{4}\right)$. However, conversion of natural to managed ecosystems (i.e., agroecosystems, urban lands, and mined lands) depletes ecosystem C stocks, aggravates gaseous emissions, and exacerbates radiative forcing. Thus, the onset of agriculture around

Rattan Lal is director of the Carbon Management and Sequestration Center, The Ohio State University, Columbus, Ohio. Pete Smith is professor of soils and global change, Institute of $\mathrm{Bi}$ ological and Environmental Sciences, University of Aberdeen, Aberdeen, United Kingdom. Hermann F. Jungkunst is professor of geoecology and physical geography, University of KoblenzLandau, Institute for Environmental Sciences in Landau, Germany. William J. Mitsch is director of Everglades Wetland Research Park, Florida Gulf Coast University, Naples, Florida. Johannes Lehmann is professor of soil and crop sciences, School of Integrative Plant Sciences, Atkinson Center for a Sustainable Future, Cornell University, Ithaca, New York. P.K. Ramachandran Nair is professor of agroforestry, School of Forest Resources and Conservation, University of Florida, Gainesville, Florida. Alex B. McBratney is professor of digital agriculture and soil sciences, School of Life and Environmental Sciences and Sydney Institute of Agriculture, The University of Sydney, New South Wales, Australia. João Carlos de Moraes Sá is an associate professor in the Department of Soil Science and Agricultural Engineering, State University of Ponta Grossa, Ponta Grossa - PR, Brazil. Julia Schneider is a postdoctoral research fellow, Institute for Environmental Sciences, University of Koblenz-Landau, Landau, Germany. Yuri Lopes Zinn and Alba Lucia Araujo Skorupa are associate professor and research associate, respectively, Department of Soil Science, Federal University of Lavras, Campus, Lavras MG, Brazil. Hai-Lin Zhang is a professor in the College of Agronomy and Biotechnology, China Agricultural University, Beijing, China. Budiman Minasny is professor of soil-landscape modelling, Sydney Institute of Agriculture, The University of Sydney, New South Wales, Australia. Cherukumalli Srinivasrao is director of the National Academy of Agriculture Research Management, Rajendranagar, Hyderabad, India. Nijavalli $\mathrm{H}$. Ravindranath is a professor, Indian Institute of Science, Bangalore, India.
8000 BC presumably transformed these sinks into a source of greenhouse gases (GHGs) (Ruddiman 2003), mostly $\mathrm{CO}_{2}$, $\mathrm{CH}_{4}$, and nitrous oxide $\left(\mathrm{N}_{2} \mathrm{O}\right)$, and depleted the terrestrial (soil, vegetation, and peatlands) C stocks. Ruddiman (2005) estimated the depletion of the terrestrial C stock (soil and vegetation) by $456 \mathrm{Pg}$ $\left(502.65 \times 10^{9} \mathrm{tn}\right)$ since the onset of agriculture. Of this, the historic depletion of soil organic carbon (SOC) stock is estimated at 130 to $135 \mathrm{Pg}\left(143.3 \times 10^{9}\right.$ to $\left.148.8 \times 10^{9} \mathrm{tn}\right)($ Sanderman et al. 2017; Lal 2018). Therefore, recarbonization of some of the terrestrial biosphere (soil and vegetation) is an important strategy to mitigate the anthropogenic climate change (ACC) and enhance other ecosystem services because of the link between SOC stock and atmospheric concentration of $\mathrm{CO}_{2}$ (Trenberth and Smith 2005).

Recarbonizing the terrestrial biosphere involves creation of a positive $\mathrm{C}$ budget in soil and vegetation through conversion to a restorative land use and adoption of best management practices (BMPs) (Smith et al. 2000; Smith 2004, 2016; Tang et al 2017). In this context, the Paris Climate Agreement recommended a voluntary plan of "4 Per Thousand" (4PT) to sequester $\mathrm{C}$ in world soils at the rate of $0.4 \%$ annually to $0.4 \mathrm{~m}(1.3 \mathrm{ft})$ depth (UNFCC 2015). Since then, there has been growing interest in soil stewardship options of low-C agriculture at global (Griscom et al. 2017; Zomer et al. 2017) and regional/ national levels (Tang et al. 2017; Sá et al 2017; Smith 2012). The objective of this article is to identify ecosystems and the available land area where the sequestration of $\mathrm{C}$ in the terrestrial biosphere (vegetation and soil) is a feasible option through conversion to a restorative land use and adoption of region-specific BMPs, and identify specific knowledge gaps where research information is lacking. The specific objective is to assess the technical potential of world soils, vegetation/forests, wetlands, and degraded ecosystems to sequester $\mathrm{C}$ following the $4 \mathrm{PT}$ initiative in order to mitigate ACC, strengthen ecosystem services, and advance the sustainable development goals of the United Nations.

\section{PRINCIPLES AND PRACTICES OF CARBON SEQUESTRATION IN TREES AND SOILS}

The basic process of $\mathrm{C}$ sequestration in the terrestrial biosphere involves transfer of atmospheric $\mathrm{CO}_{2}$ into plant biomass through photosynthesis and conversion of biomass into stable SOC through formation of organo-mineral complexes. Upon its decomposition in soil, a part of the plant biomass also forms soil inorganic carbon (SIC) as bicarbonates and carbonates. These secondary or pedogenic carbonates are formed through dissolution of $\mathrm{CO}_{2}$ into a dilute carbonic acid and its reaction with cations (e.g., calcium [Ca], magnesium $[\mathrm{Mg}]$, potassium $[\mathrm{K}]$, and sodium [Na]) added from outside the ecosystem. Photosynthesis of atmospheric $\mathrm{CO}_{2}$ into net primary productivity (NPP), retention of a part of NPP into the terrestrial biosphere as net ecosystem productivity (NEP), and formation of SOC and SIC constitute the principal processes of terrestrial $\mathrm{C}$ sequestration. Therefore, the basic strategy of terrestrial $\mathrm{C}$ sequestration is (1) enhancing NPP and NEP, and (2) increasing its storage in soil as SOC and SIC.

Whereas the NPP and NEP depend largely on an adequate supply of essential plant nutrients (both macro and micro) and available water capacity of the root zone (green water), formation of stable organo-mineral complexes as SOC depends on soil profile characteristics (i.e., depth, horizonation, texture, mineralogical composition, available water capacity, and nutrient reserves) and landscape attributes (i.e., terrain, position, aspect, and drainage). Furthermore, land use (e.g., natural, cropland, grazing land, forest land, urban land, mine land, and wetland) and management (i.e., conservation agriculture [CA], agroforestry, cover cropping, nutrient management, irrigation, crop rotation, farming/cropping system, and 
varieties) and use of amendments (e.g., biochar, compost, lime, and fertilizer) also impact the rate, cumulative amount, and the period to attain the saturation of the sink capacity. The latter also depends on the historic $\mathrm{C}$ lost or depleted from the biosphere by anthropogenic activities (Lal 2018). Sequestration of SOC happens with adoption of site-specific land use and management practices that create a positive soil/ecosystem C budget. A positive soil $\mathrm{C}$ budget implies that input of biomass$\mathrm{C}$ exceeds the cumulative loss caused by erosion, mineralization, and leaching (Lal 2018). There is no one universal practice (a panacea) to create a positive soil $\mathrm{C}$ budget. Thus, identification of context-specific practices (based on biophysical, social, economic, and cultural factors) is essential to sequestration of atmospheric $\mathrm{CO}_{2}$ into the terrestrial biosphere.

\section{LAND RESOURCES FOR CARBON SEQUESTRATION}

Obtaining reliable statistics on land resources in different biomes and identifying ecoregion-specific land use and management systems are essential to estimating the potential of $\mathrm{C}$ sequestration in the terrestrial biosphere.

Land Uses and the Corresponding Area. In this study, data on the current land uses at global levels were collated from the literature including the FAOSTAT (2015, $2016,2017)$ and articles in peer-review journals (Watson et al. 2000; Oldeman 1994; Mitsch et al. 2013; Ramankutty and Foley 1998; Bhatti et al. 2006; Lal 2003; Follett et al. 2000; Neary et al. 2003; Joosten 2010; Mitsch et al. 2010; Gorham 1991; Kurnianto et al. 2015; Trettin and Jurgensen 2003; IPCC 2000) and are outlined schematically in figure 1 . The rationale for data collation as presented in figure 1 included the following:

1. Minimize duplication and double accounting of the area among land uses and objectively assess the global land area of cropland $\left(\sim 1,500 \times 10^{6}\right.$ ha $\left[1,500\right.$ Mha; $\left.\left.3,706.575 \times 10^{6} \mathrm{ac}\right]\right)$ and grassland/grazing land (3,500 Mha $\left.\left[8,648.675 \times 10^{6} \mathrm{ac}\right]\right)$ so that the sum of different categories considered for sequestration is equivalent to the total global area under the specific land use (e.g., cropland or grazing land)

2. Identify the area affected by extreme and strong categories of land degradation (e.g., land degraded by erosion, chemical and physical processes [Oldeman 1994], and mining activities) and that can be forested or set aside for restoration

3. Assess the net rate of $\mathrm{C}$ sequestration by the application of biochar from the gross rate $\left(1.28 \mathrm{Pg} \mathrm{y}^{-1}\left[1.41 \times 10^{9} \mathrm{tn}\right.\right.$ $\mathrm{yr}^{-1}$ ]) (Woolf et al. 2010, 2016) with corrections for the energy used in pyrolysis $\left(0.58 \mathrm{Pg} \mathrm{C} \mathrm{y}^{-1}\left[0.639 \times 10^{9} \mathrm{tn}\right.\right.$

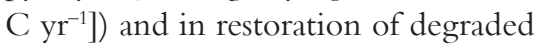
lands $\left(0.3 \mathrm{Pg} \mathrm{C}\left[0.331 \times 10^{9}\right.\right.$ tn $\left.\left.\mathrm{C}\right]\right)$ (Smith 2016)

4. Determine the land area under wetland/peatlands (Mitsch et al. 2012; Jungkunst et al. 2012) and urban lands (D'Amour 2017) with potential for terrestrial $\mathrm{C}$ sequestration
5. Establish credible ranges (minima and maxima) from the published rates of $\mathrm{C}$ sequestration in biomass and soil and obtain estimates of the equilibrium period for different land use systems to enable assessment of the cumulative technical potential (Smith 2004, 2016; Smith et al. 2008; Lal 2004, 2010; Paustian et al. 1997, 2016; Zomer et al. 2016; Rockstrom et al. 2017; Nave et al. 2018; Minx et al. 2018; Fuss et al. 2018; Nemet et al. 2018)

Thus, the land use categories identified were those that have a high $\mathrm{C}$ sink capacity due either to historic land use or to the prevalence of the specific soil degradation processes (figure 1).

Biomes with a High Net Primary Productivity and Those Where Sequestration is Feasible. Similar to the identification of the land use categories and their associated area, it is also pertinent to identify the biomes that have high terrestrial C stocks.

\section{Figure 1}

Land use categories feasible for transferring atmospheric carbon dioxide $\left(\mathrm{CO}_{2}\right)$ into vegetation and soil of the biosphere.

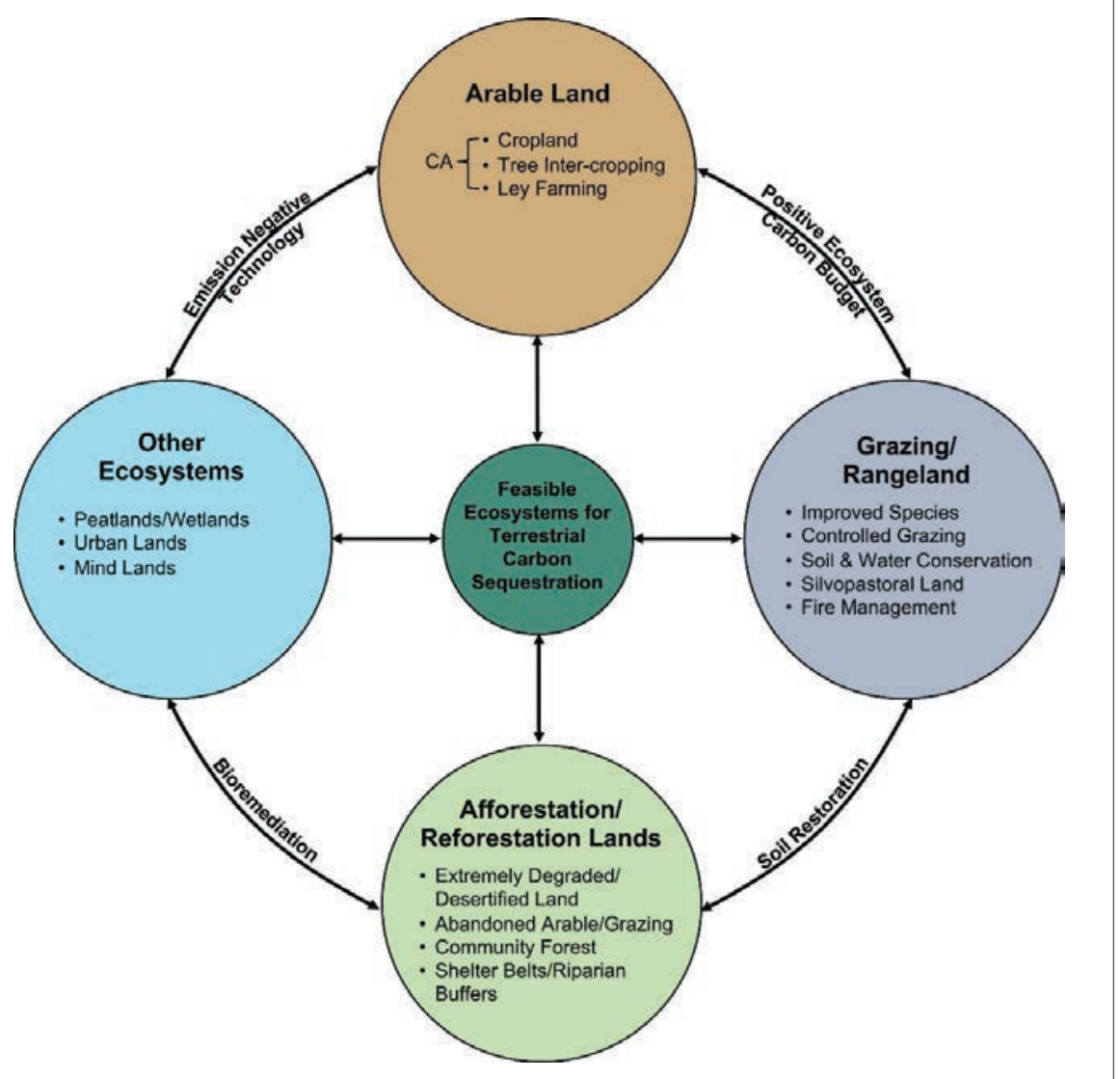


In this regard, knowledge of the ratio of the $\mathrm{C}$ stock in soil to that in vegetation for different biomes may be a useful criterion. The ratio of soil:vegetation $\mathrm{C}$ stock increases from about unity in the equatorial region to greater than 20 in boreal and tundra biomes (Watson et al. 2000; Saugier et al. 2001). Further, the global $\mathrm{NPP}$ is larger in equatorial ecoregions, decreasing from 21.9 to $0.5 \mathrm{Pg} \mathrm{C} \mathrm{y}^{-1}$ (24.1 $\times 10^{9}$ to $0.55 \times 10^{9}$ tn $\mathrm{C} \mathrm{yr}^{-1}$ ) in tundra. In the long term, however, the strategy is to enhance the storage of NPP-C in the subsoil, vegetation, and wetlands, and increase its mean residence time (MRT). Furthermore, the stock of $\mathrm{C}$ in agricultural soils may be prone to degradation (i.e., by erosion, structural decline, nutrient mining, salinization, and SOC depletion), and management options must be adopted to protect existing stocks while also creating a positive soil $\mathrm{C}$ budget to sequester new NPP-C. In addition to a low biomass-C, soils of agroecosystems also contain 25\% to $75 \%$ less SOC than their counterparts under natural ecosystems. Soil degradation creates a positive feedback to the atmosphere and also leads to a regressive decline in SOC stock along with a downward spiral of soil quality, productivity, and ecosystem services. The downward spiral can be reversed into an upward trajectory by recarbonization via $\mathrm{CO}_{2}$ sequestration in vegetation, soils, and wetlands. The upward spiral is triggered by a positive ecosystem balance between $\mathrm{C}$ gains (biomass $\mathrm{C}$ inputs) and losses (by microbial oxidation, soil erosion, and leaching). The potential of agricultural BMPs toward offsetting anthropogenic emission of GHGs, widely estimated to offset a sizable fraction of the emissions (Lam et al. 2013; Neufeldt et al. 2015; Houghton 2014; Houghton et al. 2015; Zomer et al. 2017), is reflected in the choice of the terrestrial ecosystems and specific land uses (figure 1).

\section{CHOICE OF LAND USE AND BEST MANAGEMENT PRACTICES}

It is timely to implement restorative land use and soil management systems to strengthen provisioning of ecosystem services (e.g., climate change mitigation, food and nutritional security, and water security) and also advance the goals of the
United Nations by recarbonization of the terrestrial biosphere. The latter involves a two-pronged approach: (1) adoption of BMPs on managed ecosystems, and (2) restoration of degraded/desertified ecosystems. Both strategies involve increasing (1) NPP of managed and degraded ecosystems, and (2) MRT of the C trapped in NPP by transformation into stable SOC protected against decomposition either by translocation into the subsoil or other edaphical mechanisms (Dungait et al. 2012).

\section{Adoption of Best Management Practices}

in Managed Ecosystems. Widespread adoption of site/biome-specific BMPs can harness a large $\mathrm{C}$ sink capacity, especially for depleted soil of impoverished farms, and degraded/desertified ecosystems. While there is no universal BMP applicable to some 300,000 soil series, the basic principles of creating a positive SOC budget are widely applicable. The strategy of BMPs implies choice of context-specific practices that (1) maintain continuous soil cover year-round with crop residues, mulch, and cover cropping; (2) replace nutrients harvested in the production through integrated nutrient management; (3) enhance soil structure and rhizospheric processes; and (4) improve ecoefficiency by reducing losses (by erosion, volatilization, or leaching). Notable among these options of land- and input-saving technologies with the potential of "producing more from less" while also mitigating the ACC are system-based CA; agroforestry, including intercropping with trees and silvopastoral systems, biochar, afforestation and reforestation of strong/extreme degraded soils, and other manageable forestry systems; and restoration of wetlands and peatlands.

Priority Biomes for Terrestrial Carbon Sequestration. Column one in table 1, lists the priority biomes that are manageable; respond to adoption of BMPs; and can sequester NPP-C in soil, vegetation, and wetlands. Important among these are (1) croplands; (2) grasslands/steppe; (3) abandoned, degraded/desertified, and mined lands; (4) forest/woodlands, including shelterbelts, riparian buffers, and community forests; (5) urban ecosystems; and (6) peat/wetlands. Using biochar on croplands, grazing lands, plantations, etc., is considered a negative emission technology (Smith 2016; Lehmann 2007), and its potential needs to be objectively assessed in terms of the net sequestration and with minimal double accounting. In addition to biochar, there is also a widespread interest in adopting system-based CA among low-C agricultural practices (Sá et al. 2017). All of these technologies must be objectively assessed in terms of minimizing double accounting.

\section{PRIORITY LAND USES IN CARBON SEQUESTRATION}

Principal land uses and estimates of their potential for $\mathrm{C}$ sequestration are shown in table 1 and discussed below.

Croplands. Cropland consists of land used for food production (i.e., cereals, legumes/pulses, roots, and tubers), with or without use of trees and animals, and with or without supplemental irrigation. Land use change from natural lands to croplands has contributed to the increase in atmospheric $\mathrm{CO}_{2}$, accounting for a large amount of global GHG emissions (Zomer et al. 2017; Ma et al. 2018). Rather than a source, croplands can be sink of atmospheric $\mathrm{CO}_{2}$ and $\mathrm{CH}_{4}$ with adoption of context-specific BMPs, including CA. Total area of cropland is estimated at 1,472 Mha $\left(3,637 \times 10^{6} \mathrm{ac}\right)($ FAO 2017). In general, croplands are among the most depleted of their terrestrial $\mathrm{C}$ stocks and are a high priority for SOC sequestration and the restoration of soil functions. Some severely eroded and depleted croplands may have been abandoned because of degradation (erosion, salinization, and nutrient/elemental imbalance) and desertification (Ramankutty 1998), and can be restored by afforestation.

Estimates of total area of arable land that can be managed to enhance its $\mathrm{C}$ stock include (1) 613 Mha $\left(1,514.1 \times 10^{6} \mathrm{ac}\right)$ under continuous cropping (cereal-legume rotation, root crops, etc.) manageable following a system-based CA; (2) crop-tree intercropping (agroforestry) on 600 Mha $\left(1,482.63 \times 10^{6} \mathrm{ac}\right)$ in the tropics; and (3) desertified soil comprising 43 Mha (106.3 $\left.\times 10^{6} \mathrm{ac}\right)$ of irrigated and 216 Mha (533.5 $\times 10^{6} \mathrm{ac}$ ) of rainfed land, which may be afforested to sequester $\mathrm{C}$ in both the vegetation and soil. The rate of SOC sequestration 
Table 1

Technical potential of carbon (C) sequestration in terrestrial ecosystems.

\begin{tabular}{|c|c|c|c|c|c|c|c|c|c|c|c|c|}
\hline \multirow[b]{2}{*}{ Land use } & \multirow{2}{*}{$\begin{array}{l}\text { Area } \\
\left(10^{6} \text { ha) }\right.\end{array}$} & \multicolumn{3}{|c|}{$\begin{array}{l}\text { Sequestration rate } \\
\left(\mathrm{Mg} \mathrm{C} \mathrm{ha-1} \mathrm{y}^{-1}\right)\end{array}$} & \multicolumn{2}{|c|}{$\begin{array}{l}\text { Equilibrium } \\
\text { period }(y)\end{array}$} & \multicolumn{3}{|c|}{ 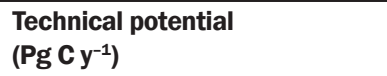 } & \multicolumn{3}{|c|}{$\begin{array}{l}\text { Cumulative potential over the } \\
\text { equilibrium period }(\mathrm{Pg} \mathrm{C})\end{array}$} \\
\hline & & Biomass & Soil & Total & Biomass & Soil & Biomass & Soil & Total & Biomass & Soil & Total \\
\hline \multicolumn{13}{|l|}{ Cropland } \\
\hline Arable & 613 & - & $\begin{array}{l}0.10 \text { to } \\
1.00\end{array}$ & $\begin{array}{l}0.10 \text { to } \\
1.00\end{array}$ & - & $\begin{array}{l}25 \text { to } \\
50\end{array}$ & - & $\begin{array}{l}0.06 \text { to } \\
0.61\end{array}$ & $\begin{array}{l}0.06 \text { to } \\
0.61\end{array}$ & - & $\begin{array}{l}2.25 \text { to } \\
22.87\end{array}$ & $\begin{array}{l}2.25 \text { to } \\
22.87\end{array}$ \\
\hline $\begin{array}{l}\text { Tree- } \\
\text { intercropping }\end{array}$ & 600 & $\begin{array}{l}0.25 \text { to } \\
0.80\end{array}$ & $\begin{array}{l}0.15 \text { to } \\
0.75\end{array}$ & $\begin{array}{l}0.40 \text { to } \\
1.55\end{array}$ & $\begin{array}{l}5 \text { to } \\
25\end{array}$ & $\begin{array}{l}25 \text { to } \\
50\end{array}$ & $\begin{array}{l}0.15 \text { to } \\
0.48\end{array}$ & $\begin{array}{l}0.09 \text { to } \\
0.45\end{array}$ & $\begin{array}{l}0.24 \text { to } \\
0.93\end{array}$ & $\begin{array}{l}2.25 \text { to } \\
7.2\end{array}$ & $\begin{array}{l}3.38 \text { to } \\
16.88\end{array}$ & $\begin{array}{l}5.63 \text { to } \\
24.08\end{array}$ \\
\hline \multicolumn{13}{|l|}{ Desertified } \\
\hline Irrigated & 43 & $\begin{array}{l}0.50 \text { to } \\
1.00\end{array}$ & $\begin{array}{l}0.5 \text { to } \\
0.75\end{array}$ & $\begin{array}{l}1.0 \text { to } \\
1.75\end{array}$ & 50 & 50 & $\begin{array}{l}0.02 \text { to } \\
0.04\end{array}$ & $\begin{array}{l}0.02 \text { to } \\
0.03\end{array}$ & $\begin{array}{l}0.04 \text { to } \\
0.07\end{array}$ & $\begin{array}{l}1.0 \text { to } \\
2.0\end{array}$ & $\begin{array}{l}1.0 \text { to } \\
1.5\end{array}$ & $\begin{array}{l}2.0 \text { to } \\
3.5\end{array}$ \\
\hline Rainfed & 216 & $\begin{array}{l}0.20 \text { to } \\
0.50\end{array}$ & $\begin{array}{l}0.10 \text { to } \\
0.20\end{array}$ & $\begin{array}{l}0.30 \text { to } \\
0.70\end{array}$ & 50 & 50 & $\begin{array}{l}0.04 \text { to } \\
0.11\end{array}$ & $\begin{array}{l}0.02 \text { to } \\
0.04\end{array}$ & $\begin{array}{l}0.06 \text { to } \\
0.15\end{array}$ & $\begin{array}{l}2.0 \text { to } \\
5.5\end{array}$ & $\begin{array}{l}1.0 \text { to } \\
2.0\end{array}$ & $\begin{array}{l}3.0 \text { to } \\
7.5\end{array}$ \\
\hline Subtotal & 1,472 & & & & & & $\begin{array}{l}0.21 \text { to } \\
0.63\end{array}$ & $\begin{array}{l}0.19 \text { to } \\
1.13\end{array}$ & $\begin{array}{l}0.40 \text { to } \\
1.66\end{array}$ & $\begin{array}{l}5.25 \text { to } \\
14.70\end{array}$ & $\begin{array}{l}7.63 \text { to } \\
43.25\end{array}$ & $\begin{array}{l}12.88 \text { to } \\
57.95\end{array}$ \\
\hline \multicolumn{13}{|l|}{ Grass/steppe } \\
\hline $\begin{array}{l}\text { Grazing/range } \\
\text { land }\end{array}$ & 2,725 & $\begin{array}{l}0.10 \text { to } \\
0.20\end{array}$ & $\begin{array}{l}0.05 \text { to } \\
0.10\end{array}$ & $\begin{array}{l}0.15 \text { to } \\
0.30\end{array}$ & $\begin{array}{l}30 \text { to } \\
50\end{array}$ & $\begin{array}{l}30 \text { to } \\
50\end{array}$ & $\begin{array}{l}0.27 \text { to } \\
0.54\end{array}$ & $\begin{array}{l}0.14 \text { to } \\
0.28\end{array}$ & $\begin{array}{l}0.41 \text { to } \\
0.82\end{array}$ & $\begin{array}{l}10.8 \text { to } \\
21.6\end{array}$ & $\begin{array}{l}5.6 \text { to } \\
11.2\end{array}$ & $\begin{array}{l}16.4 \text { to } \\
32.8\end{array}$ \\
\hline Silvopasture & 550 & $\begin{array}{l}0.30 \text { to } \\
1.00\end{array}$ & $\begin{array}{l}0.25 \text { to } \\
0.9\end{array}$ & $\begin{array}{l}0.55 \text { to } \\
1.90\end{array}$ & $\begin{array}{l}5 \text { to } \\
25\end{array}$ & $\begin{array}{l}25 \text { to } \\
50\end{array}$ & $\begin{array}{l}0.17 \text { to } \\
0.55\end{array}$ & $\begin{array}{l}0.14 \text { to } \\
0.50\end{array}$ & $\begin{array}{l}0.31 \text { to } \\
1.05\end{array}$ & $\begin{array}{l}2.6 \text { to } \\
8.3\end{array}$ & $\begin{array}{l}5.3 \text { to } \\
18.8\end{array}$ & $\begin{array}{l}7.9 \text { to } \\
27.1\end{array}$ \\
\hline $\begin{array}{l}\text { Abandoned } \\
\text { land }\end{array}$ & 48 & $\begin{array}{l}0.25 \text { to } \\
0.55\end{array}$ & $\begin{array}{l}0.20 \text { to } \\
0.50\end{array}$ & $\begin{array}{l}0.45 \text { to } \\
1.05\end{array}$ & 30 & 50 & $\begin{array}{l}0.012 \text { to } \\
0.026\end{array}$ & $\begin{array}{l}0.010 \text { to } \\
0.024\end{array}$ & $\begin{array}{l}0.022 \text { to } \\
0.05\end{array}$ & $\begin{array}{l}0.5 \text { to } \\
1.2\end{array}$ & $\begin{array}{l}0.86 \text { to } \\
1.98\end{array}$ & $\begin{array}{l}1.36 \text { to } \\
3.2\end{array}$ \\
\hline Subtotal & 3,323 & & & & & & $\begin{array}{l}0.45 \text { to } \\
1.11\end{array}$ & $\begin{array}{l}0.29 \text { to } \\
0.80\end{array}$ & $\begin{array}{l}0.74 \text { to } \\
1.91 \\
\end{array}$ & $\begin{array}{l}13.9 \text { to } \\
31.1\end{array}$ & $\begin{array}{l}11.8 \text { to } \\
32.0\end{array}$ & $\begin{array}{l}25.7 \text { to } \\
63.1 \\
\end{array}$ \\
\hline \multicolumn{13}{|l|}{ Forest/woodland } \\
\hline $\begin{array}{l}\text { Abandoned } \\
\text { croplands }\end{array}$ & 180 & $\begin{array}{l}0.2 \text { to } \\
0.8\end{array}$ & $\begin{array}{l}0.15 \text { to } \\
0.6\end{array}$ & $\begin{array}{l}0.35 \text { to } \\
1.4\end{array}$ & 80 & 50 & $\begin{array}{l}0.036 \text { to } \\
0.144\end{array}$ & $\begin{array}{l}0.027 \text { to } \\
0.108\end{array}$ & $\begin{array}{l}0.063 \text { to } \\
0.250\end{array}$ & $\begin{array}{l}2.9 \text { to } \\
11.5\end{array}$ & $\begin{array}{l}1.35 \text { to } \\
5.40\end{array}$ & $\begin{array}{l}4.25 \text { to } \\
16.90\end{array}$ \\
\hline \multicolumn{13}{|c|}{ Extremely/severely degraded lands } \\
\hline $\begin{array}{l}\text { Water } \\
\text { erosion }\end{array}$ & 224 & $\begin{array}{l}0.25 \text { to } \\
0.50\end{array}$ & $\begin{array}{l}0.05 \text { to } \\
0.75\end{array}$ & $\begin{array}{l}0.30 \text { to } \\
1.25\end{array}$ & 50 & $\begin{array}{l}25 \text { to } \\
40\end{array}$ & $\begin{array}{l}0.056 \text { to } \\
0.112\end{array}$ & $\begin{array}{l}0.011 \text { to } \\
0.168\end{array}$ & $\begin{array}{l}0.067 \text { to } \\
0.280\end{array}$ & $\begin{array}{l}2.8 \text { to } \\
5.6\end{array}$ & $\begin{array}{l}0.36 \text { to } \\
5.46\end{array}$ & $\begin{array}{l}3.16 \text { to } \\
11.06\end{array}$ \\
\hline $\begin{array}{l}\text { Wind } \\
\text { erosion }\end{array}$ & 26 & $\begin{array}{l}0.35 \text { to } \\
0.65\end{array}$ & $\begin{array}{l}0.10 \text { to } \\
0.20\end{array}$ & $\begin{array}{l}0.45 \text { to } \\
0.85\end{array}$ & 50 & $\begin{array}{l}25 \text { to } \\
50\end{array}$ & $\begin{array}{l}0.009 \text { to } \\
0.017\end{array}$ & $\begin{array}{l}0.003 \text { to } \\
0.006\end{array}$ & $\begin{array}{l}0.012 \text { to } \\
0.023\end{array}$ & $\begin{array}{l}0.45 \text { to } \\
0.85\end{array}$ & $\begin{array}{l}0.11 \text { to } \\
0.86\end{array}$ & $\begin{array}{l}0.56 \text { to } \\
1.71\end{array}$ \\
\hline Chemical & 43 & $\begin{array}{l}0.50 \text { to } \\
1.00\end{array}$ & $\begin{array}{l}1.00 \text { to } \\
2.00\end{array}$ & $\begin{array}{l}1.50 \text { to } \\
3.00\end{array}$ & 50 & 20 & $\begin{array}{l}0.022 \text { to } \\
0.044\end{array}$ & $\begin{array}{l}0.043 \text { to } \\
0.086\end{array}$ & $\begin{array}{l}0.065 \text { to } \\
0.130\end{array}$ & $\begin{array}{l}1.10 \text { to } \\
2.20\end{array}$ & $\begin{array}{l}0.86 \text { to } \\
1.72\end{array}$ & $\begin{array}{l}1.96 \text { to } \\
3.92\end{array}$ \\
\hline Physical & 12 & $\begin{array}{l}0.10 \text { to } \\
0.20\end{array}$ & $\begin{array}{l}0.30 \text { to } \\
0.40\end{array}$ & $\begin{array}{l}0.40 \text { to } \\
0.60\end{array}$ & 50 & 20 & $\begin{array}{l}0.001 \text { to } \\
0.002\end{array}$ & $\begin{array}{l}0.036 \text { to } \\
0.048\end{array}$ & $\begin{array}{l}0.037 \text { to } \\
0.050\end{array}$ & $\begin{array}{l}0.05 \text { to } \\
0.10\end{array}$ & $\begin{array}{l}0.72 \text { to } \\
0.96\end{array}$ & $\begin{array}{l}0.77 \text { to } \\
1.06\end{array}$ \\
\hline Mined & 20 & $\begin{array}{l}0.50 \text { to } \\
1.00\end{array}$ & $\begin{array}{l}0.50 \text { to } \\
1.00\end{array}$ & $\begin{array}{l}1.00 \text { to } \\
2.00\end{array}$ & 50 & 50 & $\begin{array}{l}0.01 \text { to } \\
0.02\end{array}$ & $\begin{array}{l}0.01 \text { to } \\
0.02\end{array}$ & $\begin{array}{l}0.02 \text { to } \\
0.04\end{array}$ & $\begin{array}{l}0.5 \text { to } \\
1.0\end{array}$ & $\begin{array}{l}0.5 \text { to } \\
1.0\end{array}$ & $\begin{array}{l}1.0 \text { to } \\
2.0\end{array}$ \\
\hline $\begin{array}{l}\text { Community } \\
\text { forest }\end{array}$ & 350 & $\begin{array}{l}1.00 \text { to } \\
2.00\end{array}$ & $\begin{array}{l}0.50 \text { to } \\
1.00\end{array}$ & $\begin{array}{l}1.50 \text { to } \\
3.00\end{array}$ & 80 & 50 & $\begin{array}{l}0.35 \text { to } \\
0.70\end{array}$ & $\begin{array}{l}0.175 \text { to } \\
0.350\end{array}$ & $\begin{array}{l}0.53 \text { to } \\
1.05\end{array}$ & $\begin{array}{l}28.0 \text { to } \\
56.0\end{array}$ & $\begin{array}{l}8.75 \text { to } \\
17.50\end{array}$ & $\begin{array}{l}36.75 \text { to } \\
73.5\end{array}$ \\
\hline $\begin{array}{l}\text { Shelter belts, } \\
\text { riparian, wood } \\
\text { lots, fuelwood }\end{array}$ & 450 & $\begin{array}{l}0.20 \text { to } \\
0.80\end{array}$ & $\begin{array}{l}0.15 \text { to } \\
0.6\end{array}$ & $\begin{array}{l}0.35 \text { to } \\
1.4\end{array}$ & 80 & 50 & $\begin{array}{l}0.09 \text { to } \\
0.36\end{array}$ & $\begin{array}{l}0.068 \text { to } \\
0.270\end{array}$ & $\begin{array}{l}0.16 \text { to } \\
0.63\end{array}$ & $\begin{array}{l}7.2 \text { to } \\
28.8\end{array}$ & $\begin{array}{l}3.4 \text { to } \\
13.5\end{array}$ & $\begin{array}{l}10.6 \text { to } \\
42.3\end{array}$ \\
\hline Subtotal & 1,305 & & & & & & $\begin{array}{l}0.57 \text { to } \\
1.40 \\
\end{array}$ & $\begin{array}{l}0.37 \text { to } \\
1.05 \\
\end{array}$ & $\begin{array}{l}0.94 \text { to } \\
2.45\end{array}$ & $\begin{array}{l}43.0 \text { to } \\
106.1\end{array}$ & $\begin{array}{l}16.1 \text { to } \\
46.4\end{array}$ & $\begin{array}{l}59.1 \text { to } \\
152.5 \\
\end{array}$ \\
\hline \multicolumn{13}{|l|}{ Other lands } \\
\hline Urban & 390 & $\begin{array}{l}1.00 \text { to } \\
2.00\end{array}$ & $\begin{array}{l}0.20 \text { to } \\
0.50\end{array}$ & $\begin{array}{l}1.2 \text { to } \\
2.5\end{array}$ & $\begin{array}{l}25 \text { to } \\
50\end{array}$ & 50 & $\begin{array}{l}0.39 \text { to } \\
0.78\end{array}$ & $\begin{array}{l}0.078 \text { to } \\
0.195\end{array}$ & $\begin{array}{l}0.47 \text { to } \\
0.98\end{array}$ & $\begin{array}{l}14.6 \text { to } \\
29.2\end{array}$ & $\begin{array}{l}3.9 \text { to } \\
9.8\end{array}$ & $\begin{array}{l}8.5 \text { to } \\
39.0\end{array}$ \\
\hline $\begin{array}{l}\text { Peatlands/ } \\
\text { wetlands }\end{array}$ & 700 & $\begin{array}{l}0.50 \text { to } \\
1.00\end{array}$ & $\begin{array}{l}0.50 \text { to } \\
1.50\end{array}$ & $\begin{array}{l}1.0 \text { to } \\
2.5\end{array}$ & 50 & 100 & $\begin{array}{l}0.35 \text { to } \\
0.70\end{array}$ & $\begin{array}{l}0.35 \text { to } \\
1.05\end{array}$ & $\begin{array}{l}0.70 \text { to } \\
1.75\end{array}$ & $\begin{array}{l}17.5 \text { to } \\
35.0\end{array}$ & $\begin{array}{l}35.0 \text { to } \\
70.0\end{array}$ & $\begin{array}{l}52.5 \text { to } \\
105.0\end{array}$ \\
\hline Subtotal & 1,090 & & & & & & $\begin{array}{l}0.74 \text { to } \\
1.5\end{array}$ & $\begin{array}{l}0.43 \text { to } \\
1.3 \\
\end{array}$ & $\begin{array}{l}1.17 \text { to } \\
2.7 \\
\end{array}$ & $\begin{array}{l}32.1 \text { to } \\
64.2\end{array}$ & $\begin{array}{l}38.9 \text { to } \\
79.8\end{array}$ & $\begin{array}{l}71.0 \text { to } \\
144.0\end{array}$ \\
\hline \multicolumn{13}{|c|}{ Specific management } \\
\hline Biochar & 2,030 & $\begin{array}{l}0.04 \text { to } \\
0.08\end{array}$ & $\begin{array}{l}0.21 \text { to } \\
0.46\end{array}$ & $\begin{array}{l}0.26 \text { to } \\
0.54\end{array}$ & & 100 & $\begin{array}{l}0.09 \text { to } \\
0.16\end{array}$ & $\begin{array}{l}0.43 \text { to } \\
0.94\end{array}$ & $\begin{array}{l}0.52 \text { to } \\
0.94\end{array}$ & $\begin{array}{l}5.4 \text { to } \\
9.6 \\
\end{array}$ & $\begin{array}{l}25.8 \text { to } \\
56.4 \\
\end{array}$ & $\begin{array}{l}31.2 \text { to } \\
66.0 *\end{array}$ \\
\hline Total manageable & land & 7,190 & & & & & $\begin{array}{l}2.0 \text { to } \\
4.6(3.3)\end{array}$ & $\begin{array}{l}1.7 \text { to } \\
4.6(3.2)\end{array}$ & $\begin{array}{l}3.7 \text { to } \\
9.3(6.5)\end{array}$ & $\begin{array}{l}94.3 \text { to } \\
216.1 \\
(155.2)\end{array}$ & $\begin{array}{l}114.4 \text { to } \\
241.5 \\
(178.0)\end{array}$ & $\begin{array}{l}208.7 \text { to } \\
457.6 \\
(333.2)\end{array}$ \\
\hline
\end{tabular}


ranges depending on soil, climate, and cropping system (table 1).

\section{Grass/Steppe and Rangeland}

Ecosystems. Grazing and rangelands are the most widely used agroecosystems in the world; they cover a wide range of climates, but include large areas in arid and semiarid regions. These lands, with a global area of 3,323 Mha $\left(8,211.3 \times 10^{6} \mathrm{ac}\right)(\mathrm{FAO} 2017)$ include (1) 2,275 Mha $\left(5,621.6 \times 10^{6} \mathrm{ac}\right)$ of grazing/rangeland, (2) 550 Mha $(1,359.1 \times$ $10^{6} \mathrm{ac}$ ) of silvopastoral land, and (3) 48 Mha $\left(118.6 \times 10^{6} \mathrm{ac}\right)$ of abandoned land, which is suited for afforestation. Carbon sequestration rates for grazing and rangelands are provided in table 1.

Forest/Woodland Ecosystems. Land suitable for afforestation and reforestation may include abandoned cropland; extremely degraded lands, including that affected by erosion (water, wind), chemical, and physical degradation (Oldeman 1994); and drastically disturbed mine lands. The forest land use also includes community forests, shelterbelts, woodlots, fuel wood, and riparian zones. The area under agroforestry includes tree cover on agricultural and grazing land, along with forage trees (Nair 2012; Zomer et al. 2009, 2016). Thus, manageable forest lands consist of 1,285 Mha $\left(3,175.3 \times 10^{6} \mathrm{ac}\right)$ with potential to sequester $\mathrm{C}$ in biomass and soil (table 1):

- Abandoned cropland. An estimated 180 Mha $\left(444.8 \times 10^{6} \mathrm{ac}\right)$ of abandoned croplands (Ramankutty 1998) can be afforested.

- Strong/extreme degraded land. Estimates by Oldeman (1994) indicate that degraded lands consist of (1) 224 Mha $\left(553.5 \times 10^{6} \mathrm{ac}\right)$ of land severely/strongly degraded by water erosion, (2) $26 \mathrm{Mha}$ $\left(64.2 \times 10^{6} \mathrm{ac}\right)$ of severely/strongly degraded wind-eroded land, (3) 43 Mha $\left(406.2 \times 10^{6} \mathrm{ac}\right)$ of chemically degraded land, and (4) 12 Mha $\left(29.6 \times 10^{6} \mathrm{ac}\right)$ of strong/severe degraded land by physical processes (e.g., soil structure, water retention and movement).

- Mineland. There are no credible data on the global land area affected by mining of coal, sand/gravel, minerals, brick making, and sand/gravel mining, etc. The land area affected by mining of coal is estimated at 3.4 Mha $\left(8.40 \times 10^{6} \mathrm{ac}\right)$ in the United States and 3.2 Mha (7.91 $\left.\times 10^{6} \mathrm{ac}\right)$ in China. In general, 90 ha $(222.4 \mathrm{ac})$ of land is disturbed by mining for every $1 \times 10^{6} \mathrm{Mg}\left(11.02 \times 10^{6}\right.$ tn) of coal. Thus, an estimate of 20 Mha $\left(49.4 \times 10^{6} \mathrm{ac}\right)$ of land affected by all surface mining activity may be rather conservative. Some examples of rates of $\mathrm{C}$ sequestration on mineland are given by Akala and Lal (2000), Ussiri and Lal (2006), and Ussiri et al. (2006).

- Community forests. The 350 Mha $\left(864.9 \times 10^{6} \mathrm{ac}\right)$ of community forest land is an important resource for terrestrial $\mathrm{C}$ sequestration with rates similar to those provided by Nair (2012).

- Other forests. Other forests include shelter belts, riparian buffers, woodlots, etc. The 450 Mha $\left(1,112 \times 10^{6} \mathrm{ac}\right)$ of manageable forest land is important to terrestrial C sequestration (Nair 2012).

Peatland and Wetlands. Wetlands and peatlands have significant yet still underappreciated roles in the global $\mathrm{C}$ cycle. They are also positioned in the landscape where climate change could affect them more than most other ecosystems. Yet they are probably, on a unit area basis, the best ecosystem for sequestering $\mathrm{CO}_{2}$ from the atmosphere. Therefore, they have roles both as players in, and recipients of, climate change (Mitsch and Gosselink 2007, 2015; Mitsch et al. 2013). Peat deposits in the world's wetlands, particularly in boreal and tropical regions, are substantial stores of $\mathrm{C}$ in the terrestrial biosphere (Mitsch and Wu 1995; Roulet 2000; Hadi et al. 2005). Carbon sequestration by coastal wetlands (salt marshes, mangroves, sea grasses) as blue carbon (Mcleod et al. 2011; Vaidyanathan 2011; WWF 2012; Conservation International et al. 2018) is particularly important because these wetlands do not have high $\mathrm{CH}_{4}$ emissions under natural conditions (Cabezas et al. 2018).

The measured rates of $\mathrm{C}$ sequestration in tropical wetlands include some high rates such as those for Cyperus wetlands in Uganda (Saunders et al. 2007) and Kalimantan, Indonesia (Page-Dumroese et al. 2003), but also relatively low rates such as in seasonally flooded wetlands in Costa Rica and Botswana (Bernal and Mitsch $2013 \mathrm{~b})$. The high rates of accumulation of peat in tropical wetlands may be due more to the slow decomposition of recalcitrant lignin in roots and woody material under constant high water than to high productivity of these systems (Chimner and Ewel 2004). The lower rates of $\mathrm{C}$ sequestration in seasonally flooded tropical wetlands are probably due to the high temperatures year-round, especially in the dry season when some of the $\mathrm{C}$ is oxidized, in some cases by fire.

Temperate-freshwater wetlands have some of the largest rates of $\mathrm{C}$ sequestration of any of the three climates investigated by Mitsch et al. (2013). Carbon sequestration in some temperate-zone wetlands range from 2.3 to $3.2 \mathrm{Mg} \mathrm{ha}^{-1} \mathrm{y}^{-1}$ (1.03 to $\left.1.43 \mathrm{tn} \mathrm{ac}^{-1} \mathrm{yr}^{-1}\right)$. Brix et al. (2001) estimated a high rate of greater than 5.0 $\mathrm{Mg} \mathrm{ha} \mathrm{y}^{-1}\left(2.23 \mathrm{tn} \mathrm{ac}^{-1} \mathrm{yr}^{-1}\right)$ in a productive Phragmites marsh in Denmark. Created and restored wetlands might be the best opportunity for $\mathrm{C}$ sequestration (Anderson and Mitsch 2006; Bernal and Mitsch 2013a; Euliss et al. 2006).

Urban Lands. Urban lands are an important ecosystem of the twenty-first century and beyond, especially in the context of ACC (Levine et al. 2007; Lal and Stewart 2017). The land area under urban ecosystems is estimated at 390 Mha (963.7 $\times 10^{6} \mathrm{ac}$ ) (Hooke et al. 2012) and may increase by another $150 \mathrm{Mha}\left(370.7 \times 10^{6}\right.$ ac) by 2050 (Lal 2018). Urban ecosystems have a large potential of $\mathrm{C}$ sequestration in biomass and soil (table 1) (Zirkle et al. 2011; Selhorst and Lal 2013).

POTENTIAL OF BIOCHAR BASED SYSTEMS

Biochar is the solid residue of heating biomass under total or partial exclusion of air (Lehmann 2007). This pyrolysis process generates a carbonaceous product that persists in the environment about 10 to 100 times longer than its feedstock (Lehmann et al. 2015), in which rests its ability to remove atmospheric $\mathrm{CO}_{2}$ compared to uncharred biomass added to soil (Lehmann 2007). While this change is essential for C sequestration using biochar, the system of photosynthesis, thermochemical conversion, energy production, transportation, soil effects, and alternative uses of biomass must be considered to quantify the emission balance (Gaunt and Lehmann 2008). Depending on the type of energy generated from the volatilized gases during 
pyrolysis, different tradeoffs exist between energy offsets and biochar $\mathrm{C}$ sequestration (Woolf et al. 2014). A greater total GHG reduction by adding biochar to soil than the equivalent energy production by burning the biochar (if any fossil energy can be offset) is only achieved if that biochar (a) decreases soil emissions of GHG other than the $\mathrm{C}$ from the biochar (e.g., $\mathrm{CO}_{2}$ through negative priming of native soil $\mathrm{C}$, $\mathrm{N}_{2} \mathrm{O}, \mathrm{CH}_{4}$ ) or (b) increases plant growth for biochar production or SOC accrual, or a combination. In such situations, a biochar $\mathrm{C}$ sequestration system is estimated to reduce GHG emissions at a lower financial cost than bioenergy with C capture and sequestration (Woolf et al. 2016). There may be a high technical potential of terrestrial C sequestration with the application of biochar (Woolf et al. 2010).

In addition to being an important emission neutral technology, biochar is a multifunctional option. It is difficult to specify the land area for biochar because its adoption is complementary to diverse land uses (e.g., cropland, grass/steppe lands, forest lands, or mineland), and the production can be increased from its application. Using a conservative approach, the global technical potential of the life-cycle emission reductions is estimated at $1.8 \mathrm{Pg} \mathrm{CO}_{2}-\mathrm{C}_{\text {equilavent }} \mathrm{y}^{-1}$ $\left(1.84 \times 10^{9}\right.$ tn $\left.\mathrm{CO}_{2}-\mathrm{C}_{\text {equilavent }} \mathrm{yr}^{-1}\right)$, of which the biochar production itself amounts to more than half (Woolf et al. 2010), leading to a total net negative $\mathrm{C}$ emission or actual C sequestration of 0.5 to $1.1 \mathrm{Pg} \mathrm{C} \mathrm{y}^{-1}(0.55$ to $1.21 \times 10^{9}$ tn $\left.\mathrm{C} \mathrm{yr}^{-1}\right)$, including aboveand belowground $\mathrm{C}$ accrual.

\section{CONCLUSIONS}

The data presented support the following conclusions:

1. The global technical potential of terrestrial C sequestration is some $333 \mathrm{Pg}$ C $\left(367.1 \times 10^{9}\right.$ tn C) by the end of the twenty-first century, equivalent to atmospheric $\mathrm{CO}_{2}$ drawdown of 156 $\mathrm{ppm}$. This must be considered objectively by policymakers and those at all levels of planning and management.

2. Such a vast potential has numerous cobenefits, with strong impacts on sustainable development goals of the United Nations, including those of zero hunger, water and sanitation, climate action, and life on land. The strong links between these goals and C sequestration must be recognized and action taken.

3. The potential can only be realized through the adoption of BMPs by farmers and land managers. Incentivizing through just and fair payments for ecosystem services is an important consideration, as are marketbased mechanisms.

4. There are numerous knowledge gaps in (a) identification and mapping of the manageable land area of cropland, grazing land, degraded/abandoned land, mine land, urban land, community forests, and wetland/peatlands; and (b) developing databases of rates of $\mathrm{C}$ sequestration in biomass and soil along with the equilibrium period for the above-listed ecosystems, but especially for wetland/peatlands, degraded lands, mineland agroforestry systems, biochar amendments, system-based C, and nutrient management systems.

5. A global research project must be implemented to validate the net rate of terrestrial $\mathrm{C}$ sequestration; the magnitude, equilibrium period, MRT, and impact on productivity in relation to soil condition and capability; and ecoefficiency. The project should submit a five-year report and create a quantitative digital map product for global understanding, policy, and management.

6. Conservation agriculture is our best current bet for effective soil $\mathrm{C}$ sequestration. This technology is about 50 years old, however. We should strive for new economic management technologies to hasten sequestration and improve soil productivity and function. This is a major challenge for soil scientists and agronomists.

\section{REFERENCES}

Akala, V.A., and R. Lal. 2000. Potential of mineland reclamation for soil C sequestration in Ohio. Land Degradation and Development 11:289-297.

Anderson, C.J., and W. Mitsch. 2006. Sediment, carbon, and nutrient accumulation at two 10-year-old created riverine marshes. Wetlands 26:779-792.

Bernal, B., and W. Mitsch. 2013a. Carbon sequestration in two created riverine wetlands in the midwestern United States. Journal of Environmental Quality 42:1236-1244.

Bernal, B., and W.J. Mitsch. 2013b. Carbon sequestration in freshwater wetlands in Costa Rica and Botswana. Biogeochemistry 115:77-93.

Bhatti, J.S., R. Lal, M.J. Apps, and M.A. Price (Eds). 2006. Climate Change and Managed Ecosystems. Boca Raton:Taylor and Francis.

Brix, H., B.K. Sorrell, and B. Lorenzen. 2001. Phragmites-dominated wetlands a net source or net sink of greenhouse gases? Aquatic Botany 69:313-324.

Cabezas, A., W. Mitsch, C. MacDonnell, L. Zhang, F. Bydalek, and A. Lasso. 2018. Methane emissions from mangrove soils in hydrologically disturbed and reference mangrove tidal creeks in southwest Florida. Ecological Engineering 114:57-65.

Chimner, R.A., and K.C. Ewel. 2004. Differences in carbon fluxes between forested and cultivated Micronesian tropical peatlands. Wetlands, Ecology and Management 12:419-427.

Conservation International, International Union for Conservation of Nature, and Intergovernmental Oceanographic Commission of the United Nations Educational, Scientific, and Cultural Organization. 2018. The Blue Carbon Initiative: Mitigating Climate Change through Coastal Ecosystem Management. http://thebluecarboninitiative.org/.

D’Amour, C.B., F. Reitsma, G. Baiocchi, S. Barthel, B. Guneralp, K.H. Erb, H. Haberl, F. Creutzig, and K.C. Seto. 2017. Future urban land expansion and implications for global croplands. Proceedings of the National Academy of Science 114(34):8939-9844.

Dungait, J., A.S. Gregory, D.W. Hopkins, and A.P. Whitmore. 2012. Soil organic matter turnover is governed by accessibility not recalcitrance. Global Change Biology 18:1781-1796.

Euliss, N.H., R.A.Gleason, A. Olness, R.L. McDougal, H.R. Murkin, R.D. Robarts, R.A. Boubonniere, and B.G. Warner. 2006. Northern American prairie wetlands are important nonforested land-based carbon storage sites. Science of the Total Environment 361:179-188.

FAO (Food and Agriculture Organization of the United Nations). 2015. Land use. Rome: Food and Agriculture Organization of the United Nations. http://www.fao.org/faostat/en/\#home. FAO. 2016. State of the World's Forests. Rome: Food and Agriculture Organization of the United Nations. http://www.fao.org/publications/sofo/2016/en/. FAO. 2017. Data. Rome: Food and Agriculture Organization of the United Nations. http:// www.fao.org/faostat/en/\#data. 
Follett, R.F., J.M. Kimble, and R. Lal (Eds). 2000. The Potential of US Grazing Lands to Sequester Carbon and Mitigate the Greenhouse Effect, 401-438. Boca Raton, FL: Lewis Publishers.

Fuss, S., W.F. Lamb, M.W. Callaghan, J. Hilaire, F. Creutzig, T. Amann, T. Beringer, et al. 2018. Negative emissions- Part 2: costs, potentials and side effects. Environmental Research Letters 13:063002.

Gaunt, J., and J. Lehmann. 2008. Energy balance and emissions associated with biochar sequestration and pyrolysis bioenergy production. Environmental Science and Technology 42:4152-4158.

Gorham, E. 1991. Northern peatlands: Role in the carbon cycle and probable responses to climatic warming, Ecological Applications 1:182-1995.

Griscom, B.W., J.Adams, P.W.Ellis, R.A. Houghton, G. Lomax, D.A. Miteva,W.H. Schlesinger, et al. 2017. Natural climate solutions. Proceedings of the National Academy of Science 114:11645-11650.

Hadi, A., K. Inubushi, Y. Furukawa, E. Purnomo, M. Rasmadi, and H. Tsuruta. 2005. Greenhouse gas emissions from tropical peatland of Kalimantan, Indonesia. Nutrient Cycling in Agroecosystems 71:73-80.

Hooke, R.L., J.F. Martin-Duque, and J. Pedraza. 2012. Land transformation by humans. GSA Today 22(12), doi:10.1130/GSAT151A.1.

Houghton, R.A. 2014. Contemporary C cycle. Treatise on Geochemistry 399-435.

Houghton, R.A., B. Byers, and A.A. Nassikas. 2015.A role for tropical forests in stabilizing atmospheric $\mathrm{CO}_{2}$. Nature Climate Change 5:1022-1023.

IPCC (International Panel on Climate Change). 2000. Good Practice Guidance for Land Use Change and Forestry. Kangawa, Japan: Institute for Global Environmental Strategies for International Panel on Climate Change.

Joosten, H. 2010. The global $\mathrm{CO}_{2}$ picture. Peatland status and drainage related emissions in all countries of the world. Wageningen: Wetlands International.

Jungkunst, H.F., J.P. Krüger, F. Heitkamp, S. Erasmi, S. Glatzel, S. Fiedler, and R. Lal. 2012. Accounting more precisely for peat and other soil carbon resources. In Recarbonization of the Biosphere, eds. R. Lal et al., 127-157. Dordrecht, Holland: Springer.

Kurnianto, S., M. Warren, J. Talbot, B. Kauffman, D. Murdiyarso, and S. Frolking. 2015. Carbon accumulation of tropical peatlands over millennia: A modeling approach. Global Change Biology 21:431-444.

Lal, R. 2003. Off-setting global $\mathrm{CO}_{2}$ emissions by restoration of degraded soils and intensification of world agriculture and forestry. Land Degradation and Development 14:309.
Lal, R. 2004. Soil carbon sequestration impacts on global climate change and food security. Science 304:1623-1627.

Lal, R. 2010. Managing soils and ecosystems for mitigating anthropogenic carbon emissions and advancing global food security. BioScience 60:708-721.

Lal, R. 2018. Digging deeper: A holistic perspective of factors affecting soil organic carbon sequestration in agroecosystems. Global Change Biology 24(8):1-17.

Lal, R., and B.A. Stewart. 2017. Urban Soils. Boca Raton: CRC Press.

Lam, S.K., D.L. Chen, A.R. Mosier, and R. Roush. 2013. The potential for carbon sequestration in Australian agricultural soils is technically and economically limited. Scientific Reports 3:2179.

Lehmann, J. 2007 A handful of carbon. Nature 447:143-144.

Lehmann, J., S. Abiven, M. Kleber, G. Pan, B.P. Singh, S. Sohi, and A. Zimmerman. 2015. Persistence of biochar in soil. In Biochar for Environmental Management: Science, Technology and Implementation, eds. J. Lehmann and S. Joseph, 235-282. London: Taylor and Francis.

Levine, J.S., J.M. Matter, D. Goldberg, A. Cook, and K.S. Lackner. 2007. Gravitational trapping of carbon dioxide in deep sea sediments: Permeability, buoyancy, and geomechanical analysis. Geophysical Research Letters 34:L24703.

Ma, S.T., X. Zhao, P. Chao,Y. Liu, R. Lal, J.F. Xue, and H.L. Zhang. 2018. Enhancing soil organic carbon by managing nitrogen in China. In Soil Nitrogen Uses and Environmental Impacts, eds. R. Lal and B.A. Stewart, 231-254. Boca Raton: CRC Press.

Mcleod, E., G.L. Chmura, S. Bouillon, R. Salm, M. Bjork, C.M. Durate, C.E. Lovelock, W.H. Schlesinger, and B.R. Silliman. 2011. A blueprint for blue carbon: Toward an improved understanding of the role of vegetated coastal habits in sequestering $\mathrm{CO}_{2}$. Frontiers in Ecology and the Environment 9:552-560.

Minx, J.C., W.F. Lamb, M.W. Callaghan, S. Fuss, J. Hilaire, F. Creutzig, T. Amann, et al. 2018. Negative emissions- Part 1: Research landscape and synthesis. Environmental Research Letters 13:063001.

Mitsch, W.J., and J.G. Gosselink. 2007. Wetlands, 4th ed. Hoboken: John Wiley and Sons, Inc.

Mitsch, W.J., and J.G. Gosselink. 2015. Wetlands, 5th ed. Hoboken: John Wiley and Sons, Inc.

Mitsch, W.J., B. Bernal, A.M. Nahlik, U. Mander, L. Zhang, C.J. Anderson, S.E. Jorgensen, and H. Brix. 2013. Wetlands, carbon and climate change. Landscape Ecology 28:583-597.
Mitsch, W.J., A. Nahlik, P. Wolski, B. Bernal, L. Zhang, and L. Ramberg. 2010. Tropical wetlands: Seasonal hydrologic pulsing, carbon sequestration, and methane emissions. Wetlands Ecology and Management 5:573-586.

Mitsch, W.J., and X. Wu. 1995. Wetlands and global change. In Advances in Soil Science, Soil Management and Greenhouse Effect, eds. R. Lal, J. Kimble, E. Levine, and B.A. Stewart. Boca Raton: CRC Press.

Mitsch, W.J., L. Zhang, K.C. Stafanik, A.M. Nahlik, C.J. Anderson, B. Bernal, M. Hernandez, and K. Song. 2012. Creating wetlands: Primary succession, water quality changes, and self-design over 15 years. Bioscience 62:237-250.

Nair, P.K.R. 2012. Climate change mitigation and adaptation: A low hanging fruit of agroforestry. In Agroforestry: The future of global land use, eds. P.K.R. Nair and D.P. Garrity, 31-67. Dordrecht: Springer.

Nave, L.E., G.M. Domke, K.L. Hofmeister, U. Mishra, C.H. Perry, B.F. Walters, and C.W. Swanston. 2018. Reforestation can sequester two petagrams of carbon in US topsoils in a century. Proceedings of the National Academy of Science 115(11):22776-2781.

Neary, D.G., S.T. Overby, and S.C. Hart. 2003. Soil carbon in arid and semi-arid ecosystems. In The Potential of US Forests Soils to Sequester Carbon and Mitigate the Greenhouse Effect, eds. J.M. Kimble, L.S. Heath, R.A. Birdsey, and R. Lal, 249310. Boca Raton: Lewis Publishers.

Nemet, G.F., M.W. Callaghan, F. Cruetzig, S. Fuss, J. Hartmann, J. Hilaire, W.F. Lamb, J.C. Minx, S. Rogers, and P. Smith. 2018. Negative emissionsPart 3: Innovation and upscaling. Environmental Research Letters 13:063003.

Neufeldt, H., G. Kissinger, and J. Alcamo. 2015. No-till agriculture and climate change mitigation. Nature Climate Change 5:488-489.

Oldeman, L.R. 1994. The global extent of soil degradation. In Soil Resilience and Sustainable Land Use, eds. D.J. Greenland and I. Szabolcs, 99-118. Wallingford, UK: CAB International.

Page-Dumroese, D., M.F. Jurgensen, and A.E. Harvey. 2003. Fire and fire- suppression impacts. In The Potential of US Forest Soils to Sequester Carbon and Mitigate the Greenhouse Effect, eds. J.M. Kimble, L.S. Heath, R.A. Birdsey, and R. Lal, 201210. Boca Raton: CRC Press.

Paustian, K., O. Andersen, H.H. Janzen, R. Lal, P. Smith, G.Tian, H.Tiessen, M.Van Nordwijk, and P.L. Woomer. 1997. Agricultural soils as a sink to mitigate emissions. Soil Use and Management 13:230-244. 
Paustian, K., J. Lehmann, S. Ogle, D. Reay, G.P. Roberston, and P. Smith. 2016. Climate-smart soils. Nature 532:49-57.

Ramankutty, N., and J.A. Foley. 1998. Characterizing patterns of global land use:An analysis of global croplands data. Global Biogeochemical Cycles 12:667-685.

Rockström, J., O. Gaffney, J. Rogelj, M. Meinshausen, N. Nakicenovic, and H.J. Schellnhuber. 2017. A roadmap for rapid decarbonization. Science 355:1269-1271.

Roulet, N.T. 2000. Peatlands, carbon storage, greenhouse gases, and the Kyoto Protocol: Prospect and significance for Canada. Wetlands 20:605-615.

Ruddiman, W. 2003. The anthropogenic greenhouse era began thousands of years ago. Climatic Change 61:261-93.

Ruddiman, W.F. 2005. Plows, Plagues and Petroleum: How Humans Took Care of Climate. Princeton: Princeton University Press.

Sá, J.C.M., R. Lal, C.C. Cerri, K. Lorenz, M. Hungria, and P.C.F. Carvalho. 2017. Low-carbon agriculture in South America to mitigate global climate change and advance food security. Environment International 98:102-112.

Sanderman, J., T. Hengl, and G.J. Fiske. 2017. Soil carbon debt of 12,000 years of human land use. Proceedings of the National Academy of Sciences 114:9575-9580.

Saugier, B., J. Roy, and H. Mooney 2001. Estimation of the global terrestrial productivity: Covering towards a single number? In Terrestrial Global Productivity, eds. J. Roy, B. Saugier, and H.A. Mooney. New York: Academic Press.

Saunders, M., F. Kansiime, and M. Jones. 2007. Carbon and water cycles in tropical papyrus wetlands. Wetlands Ecology Management 15:489-498.

Selhorst, A., and R. Lal. 2013. Net carbon sequestration potential and emissions in home lawn turfgrass of the United States. Environmental Management 51(1):198-208.

Smith, P. 2004. Carbon sequestration in croplands: The potential in Europe and the global context. European Journal of Agronomy 20:229-236.

Smith, P. 2012. Agricultural greenhouse gas mitigation potential globally, in Europe and the UK: What have we learnt in the last 20 years? Global Change Biology 18:35-43.

Smith, P. 2016. Soil carbon sequestration and biochar as negative emission technologies. Global Change Biology 22:1315-1324.

Smith, P., D. Martino, Z. Cai, D. Gwary, H. Jenzen, P. Kumar, B. McCarl, et al. 2008. Greenhouse gas mitigation in agriculture. Philosophical Transactions of the Royal Society (B): Biological Sciences 363:789-813.
Smith, P., D.S. Powlson, J.U. Smith, P. Falloon, and K. Coleman. 2000. Meeting Europe's climate change commitments: Quantitative estimates of the potential for carbon mitigation by agriculture. Global Change Biology 6:525-539.

Tang, X., X. Zhao, Y. Bai, Z. Tang, W. Wang, Y. Zhao, et al. 2017. Carbon pools in China's terrestrial ecosystems: New estimates based on an intensive field survey. Proceedings of the National Academy of Science of the United States of America 115:4021-4026.

Trenberth, K.E., and L. Smith. 2005. The mass of the atmosphere: A constraint on global analyses. Journal of Climate 18:864-875.

Trettin, S.C., and M.F. Jurgensen. 2003. Carbon cycling in wetlands forest soils. In The Potential of US Forests Soils to Sequester Carbon and Mitigate the Greenhouse Effect, eds.J.M. Kimble, L.S. Heath, R.A. Birdsey, and R. Lal, 311-330. Boca Raton: Lewis Publishers.

UNFCC (United Nations Framework Convention on Climate Change). 2015. COP21 Climate Agreement. Paris, France: United Nations Framework Convention on Climate Change.

Ussiri, D.A.N., and R. Lal. 2006. Carbon sequestration in reclaimed minesoils. Critical Reviews in Plant Sciences 24:151-165.

Ussiri, D.A.N., R. Lal, and P.A. Jacinthe. 2006. Post reclamation land use effects on soil properties and carbon sequestration in minesoils of southeastern Ohio. Soil Science 171:261-271.

Vaidyanathan, G. 2011. 'Blue Carbon' plant takes shape. Nature News 21.1.

Watson, R.T., I.R. Noble, B. Bolin, N.H. Ravindranath, D.J. Verardo, and D.J. Dokken (Eds). 2000. Land Use, Land Use Change and Forestry. A Special Report of International Panel on Climate Change. Cambridge, UK: Cambridge University Press.

Woolf, D., J.E. Amonette, F.A. Street-Perrott, J. Lehmann, and S. Joseph. 2010. Sustainable biochar to mitigate global climate change. Nature Communications 1:56.

Woolf, D., J. Lehmann, E. Fisher, and L. Angenent. 2014. Biofuels from pyrolysis in perspective: Trade-offs between energy yields and soilcarbon additions. Environmental Science and Technology 48:6492-6499.

Woolf, D., J. Lehmann, and D. Lee. 2016. Optimal bioenergy power generation for climate change mitigation with or without carbon sequestration. Nature Communications 7:13160.

WWF (World Wildlife Fund). 2012. Living planet report. Gland, Switzerland: World Wildlife Fund. http://wwf.panda.org/knowledge_hub/ all_publications/living_planet_report_timeline/ lpr_2012/.

Zirkle, G., R. Lal, and B. Augustin. 2011. Modeling carbon sequestration in home lawns. HortScience 46:808-814.

Zomer, R.J., D.A. Bossio, R. Sommer, and L.V. Verchot. 2017. Global sequestration potential of increased organic carbon in cropland soils. Scientific Reports 7:15554.

Zomer, R.J., H. Neufeldt, J. Xu, A. Ahrends, D. Bossio, A. Trabucco, M. van Noordwijk, and M. Wang. 2016. Global tree cover and biomass carbon on agricultural land: The contribution of agroforestry to global and national carbon budgets. Scientific Reports 6:29987.

Zomer, R.J., A. Trabucco, R. Coe, and F. Place. 2009. Trees on farm: Analysis of global extent and geographical patterns of agroforestry. ICRAF Working Paper No. 89. Nairobi, Kenya: World Agroforestry Centre. http://www.worldagroforestry.org/downloads/Publications/PDFs/ WP16263.PDF. 